The Relationship between Buyer and a B2B e-Marketplace:

Cooperation Determinants in an Electronic Market Context*

\author{
Andrew Lancastre** \\ and \\ Luis Filipe Lages***
}

2004

* This research was funded by a research grant from the 6th European Framework Program, Specific Support Action-CoCombine. Andrew Lancastre acknowledges UNIDCOM/IADE and Luis Filipe Lages is grateful to "Nova Égide".

** Andrew Lancastre is affiliated with ISCTE Business School-Lisbon, and IADE Instituto de Artes Visuais, Design e Marketing, Av. D.Carlos I, nº 4, 1200 - Lisbon, Portugal. Phone: + 351.21.3939686, Fax: + 351.21.3937856, alancastre@iade.pt

*** Luis Filipe Lages is Assistant Professor of Marketing and International Business at Universidade Nova de Lisboa, Faculdade de Economia, Campus de Campolide, 1099-032 Lisboa, Portugal. Phone: + 351.21.3801.600, fax: + 351.21.3886.073, lflages@fe.unl.pt, http://docentes.fe.unl.pt/ lflages 


\title{
The Relationship between Buyer and a B2B e-Marketplace: Cooperation Determinants in an Electronic Market Context
}

\begin{abstract}
In this article, the authors argue that cooperation may be achieved by adding technology dimensions to the core product.

Given the growing importance of real time information exchange and interactivity, a better understanding of the use of technology to the establishment and development of the buyer-supplier cooperative relationships is essential for knowledge advancement. Using a sample of nearly 400 SME's purchasing managers, this paper reveals that in an electronic market context, cooperation is positively affected by termination costs, supplier policies and practices, communication and information exchange, and negatively affected by product prices and opportunistic behavior. Moreover, both relationship commitment and trust play a major role in mediating the relationships between these five determinants and cooperation.
\end{abstract}

Keywords: relationship marketing, trust, cooperation, electronic markets, e-commerce 


\section{The Relationship between Buyer and a B2B e-Marketplace:}

\section{Cooperation Determinants in an Electronic Market Context}

"To be an effective competitor in the global economy requires one to be a trusted cooperator in some network (...). Relationship marketing, in all its contexts, requires cooperative behaviors."

(Morgan and Hunt, 1994)

"Electronic commerce has added a whole new dimension to discussions of business relationships."

(Morgan and Hunt, 2003)

In a highly-competitive context, firms' increasing costs in customer acquisition enhance the suppliers' need to create and develop cooperative relationships with their customers (Doney and Cannon, 1997; Reichheld and Sasser, 1990). Cooperation refers to situations in which parties work together to achieve mutual goals, leading to outcomes that exceed what any of the firms involved would achieve if it acted solely in its own best interests (Anderson and Narus, 1990), and cooperative relationships are characterized by high levels of trust (Dwyer, Schurr, and Oh, 1987; Morgan e Hunt, 1994). As far as marketers place an increasing emphasis on building long term relationships, trust assumes a central role in the development of marketing theory and marketing practice (Dertouzos, Lester and Solow, 1989; Dwyer, Schurr, and Oh, 1987), representing one of the most essential ingredients in the creation and development of cooperation between buyers and suppliers (Anderson and Narus, 1990; Ganesan, 1994). However, when comparing future intentions of customers with weak and strong relationships, Garbarino and Johnson (1999) found that the last are driven by both trust and relationship commitment, meaning that these two dimensions are essential mediators between component attitudes and cooperation. In fact, because 
relationships characterized by trust are so highly valued, partners will desire to commit themselves to such relationships (Morgan and Hunt, 1994).

Despite the development and progress in the understanding of Relationship Marketing (RM), much that has been researched has not attempted to address its implementation in organizations (Gummesson, 1994; Too, Souchon, and P. Thirkell, 2001). RM definitions are mainly aimed at the desired outputs, forgetting the required inputs or features, which would enable an observer to determine if a marketing relationship policy was followed by the organization (Blois, 1996). Additionally, from the customer viewpoint, the issue of why consumers may want a marketing relationship with a firm, or what benefit they may perceive from a cooperative relationship, remains under-explored (Garbarino and Johnson, 1999).

Electronic markets are defined as networked information systems that serve as an enabling infrastructure for buyers and sellers to exchange information, transact, and perform other activities related to the transaction before, during, and after transaction (Varadarajan and Yadav, 2002). From a cooperation perspective, electronic marketing (e-marketing) covers all orientations that allow relational exchanges in network, interactive, digital contexts; where security, privacy, convenience and customer service support represent new marketing roles (Kalyanam and McIntyre, 2002). In this context, where business is conducted at a distance and risks and uncertainties are magnified, trust becomes even more important in gaining the commitment of the customers and their cooperation, than in the traditional context. In fact, when customers trust the on-line vendor, they are much more likely to be committed and cooperate, by opening their communication with the supplier, and sharing personal information. This allows the supplier to customize the offer, which in turn increases trust and strengthens the relationship (Reichheld and Schefter, 2000). 
Despite the interest of practitioners and academicians on electronic markets, concerted efforts to understand them have been lacking (Grewal, Comer, and Mehta, 2001). Furthermore, it has been observed that most firms do not acknowledge the impact of new information and communication technologies, and the potential of emarketing, on customer attitudes and behavior (Coviello, Milley, Marcolin, 2001). As observed by Morgan and Hunt (2003), a number of questions emerge from this new context, namely: are relationships established in the bricks-and-mortar world transferable to the firm's Web presence? How do firms develop a reputation for trust among customers whom they never see in person? This is particularly important in the case of SMEs (small and medium-sized enterprises), where the development and implementation of customer retention strategies, and the use of electronic means for relationship development and cooperation purposes are seldom a characteristic.

Our research will focus on the extent to which the information and communication technologies (ICT) may contribute to the buyer-seller cooperative relationship, in an electronic market context. It is our objective to extend, from a buyer's perspective, our understanding of the following issues:

1. key determinants of buyer-seller cooperation;

2. the mediating effects of trust and commitment on the buyer-seller cooperative relationship;

3. the effects of trust on relationship commitment.

To do so, in the subsequent sections, we present the theoretical background, namely the nature of cooperation. We then present research hypotheses, research methodology, and report the results. Finally, we discuss the limitations of our research and the implications of our findings. 


\section{CONCEPTUAL FRAMEWORK}

One central idea underlying relationship marketing is that the goal of marketers is to nurture long-term relationships by means of a structure of mutual benefits for the parties involved (Hewett and Bearden, 2001). These benefits can be achieved through cooperative actions undertaken by the parties. Morgan and Hunt (1994, p.26) suggest that cooperation requires the two parties in a relationship to participate actively to achieve mutual benefits and that cooperation promotes success in the relationship. Cooperation can then be defined as similar or complementary coordinated actions taken by firms in interdependent relationships to achieve mutual outcomes or singular outcomes with expected reciprocation over time (Anderson and Narus, 1990). In an emarket environment we view buyer-cooperation in terms of the interactions and communication activities with the supplier (Hewett and Bearden, 2001).

In view of the objectives mentioned above, we propose a conceptual model and hypotheses based on the "commitment-trust" approach (Morgan and Hunt, 1994; Morgan, 2000). Morgan and Hunt's (1994) theory holds that both commitment and trust are key variables, essential to the process of building cooperative marketing relationships. More recently, Morgan (2000) suggests that the development of the mediators and effective cooperation in marketing relationships depends on three sets of dimensions - economic, resources, and social contents. First, relationships that provide partners with superior economic benefits will foster effective cooperation, and thus relationship preservation and success. These economic benefits and costs constitute the economic content (Morgan, 2000). Literature suggests that economic relationship benefits, namely for buyers in the virtual marketplaces, may include 
market-driven product pricing and savings on acquisition costs (Klein and Quelch, 1997), as well as relationship termination costs (Morgan and Hunt, 1994).

Second, the resource content may include benefits to the relationship such as convenient and rapid procurement (e.g. larger assortment and variety, easier and faster ordering and service delivery), security, and privacy, offered by the supplier in an ICT context (Berry, Seiders, and Grewal, 2002; Zeithaml, Parasuraman, and Malhotra, 2002). These benefits, combined with partners' own resources, may increase the efficiency of the partners' value chain activities, and promote effective cooperation within marketing relationships (Porter, 2001; Rayport and Sviokla, 1995; Weiber and Kollmann, 1998). Finally, the social content, through which partners perceive their current and future compatibility, results from the sharing of similar cultures, information, open communication, and partner's behavior (Morgan and Hunt, 1994; Sivadas and Dwyer, 2000). In an ICT context, these technologies act as a dialogue stimulator, facilitating interactivity and real time relevant information exchange between buyers and sellers (McKenna, 1997; Weiber and Kollmann, 1998). While building on different domains of relationship marketing literature and exploratory analysis findings, we developed a conceptual framework (see Figure 1), which systematizes key determinants of cooperation.

Take in Figure 1

More specifically, the distinct characteristics of the e-market, such as its interactivity (Kalyanam and McIntyre, 2002), real time functionality (McKenna, 1997), and convenience (Berry, Seiders, and Grewal, 2002), make the direct translation of constructs from other relationship market contexts difficult and sometimes 
inappropriate. To overcome this obstacle we have also built on the consumer-firm exchanges literature (Garbarino and Johnson, 1999; Sirdeshmukh, Singh, and Sabol, 2002), and service exchanges in a web context (Grewal, Comer, and Mehta, 2001; Zeithaml, Parasuraman, and Malhotra, 2002).

In this section we begin by developing the hypotheses associated with the precursors of buyer-supplier cooperation. We propose that cooperation is affected by a set of determinants in an e-market context, through the mediating effect of trust and relationship commitment. More specifically we suggest that product prices, acquisition costs, termination costs, pre-acquisition benefits, and post-acquisition benefits affect cooperation through their impact on relationship commitment. Additionally, opportunistic behavior, communication, and information exchange affect cooperation through the mediating effect of trust. Moreover, we suggest that supplier policies and practices affect cooperation through both the mediating variables, while trust itself has a direct effect on relationship commitment.

\section{Precursors of Cooperation}

\section{The Effects of Relationship Commitment on Cooperation}

Relationship commitment and trust are sentiments that have been identified as being critically important in the development of long-term firm relationships (Anderson and Narus, 1990; Dwyer, Schurr, and Oh, 1987; Kumar, Sheer, and Steenkamp, 1995; Morgan and Hunt, 1994). Commitment and trust are "key" because they encourage marketers to 1) work at preserving relationship investments by cooperating with exchange partners, 2) resist attractive short-term alternatives in favor of the expected long-term benefits of staying with existing partners, and 3) view potentially high-risk actions as being prudent because of the belief that partners will not act 
opportunistically. In short, commitment and trust lead directly to cooperative behaviors that are conducive to relationship marketing success (Morgan and Hunt, 1994).

Commitment to the relationship is defined as an enduring desire to maintain a valued relationship (Moorman, Zaltman, and Deshpandé, 1992). Commitment has three components: an instrumental component of some form of investment, an attitudinal component that may be described as effective commitment or psychological attachment (e.g. customer pride in being associated with the supplier), and a temporal dimension indicating that the relationship exists over time (Garbarino and Johnson, 1999). In inter-organizational relationships, such as this research setting, commitment is the desire to develop a stable relationship, a willingness to make short-term sacrifices to maintain the relationship, and a confidence in the stability of the relationship (Anderson and Weitz, 1992). It implies the adoption of a long-term orientation toward the relationship - short-term sacrifices to realize long-term benefits - an implicit or explicit pledge of relational continuity between exchange partners (Dwyer, Schurr, and Oh, 1987). Suppliers in a committed relationship gain greater access to market information for developing products (Anderson and Weitz, 1992), or select a better customer-oriented assortment. Buyers in the e-market will receive more relevant on-time market and product information (Weiber and Kollman, 1998; Smith, Bailey, and Brynjolfsson, 1999), a better assortment choice, and a more efficient service delivery. Because both parties receive valued contributions from each other, each partner has a strong motivation to build, maintain, strengthen and deepen the relationship, making it more likely that they perceive their relationship as a win-win opportunity (Kumar, Scheer, and Steenkamp, 1995), and cooperation as a means to develop it. Specifically, we hypothesize: 


\section{Hypothesis 1: There is a positive relationship between relationship commitment and cooperation}

\section{The Effects of Trust on Cooperation}

The evolution of competition forces firms to cope with an increasing difficulty in the management of technological options and market relations. Technologies are in continuous incessant development, and market relations are frequently threatened by new or more aggressive competitors. Most firms have reacted to this dynamic by trying to develop long-term cooperative relationships with their clients, based on mutual trust (Raimondo, 2000). In fact, relational exchanges differentiate from discrete transactions along several key dimensions. The most important difference is the fact that relational exchange transpires over time; each transaction must be viewed in terms of its history and its anticipated future, suggesting that the basis for future collaboration may be supported by implicit and explicit assumptions, trust, and planning (Dwyer, Schurr, and Oh, 1987).

Trust exists when one party has confidence in an exchange partner's reliability and integrity, which is associated with qualities such as consistency, competency, honesty, fairness, responsibility, helpfulness and benevolence (Morgan and Hunt, 1994). Once trust is established, firms learn that coordinated joint efforts will lead to outcomes that exceed what the firm would achieve if it acted solely in its own best interests, sometimes willing to temporarily postpone the receipt of its own outcomes until some later time (Anderson and Narus, 1990). So trust is a working relationship, and this fact has repercussions on the firm's actions. These repercussions can be defined as the firm's belief that another company will perform actions that will result in positive 
outcomes for the firm, as well as not take unexpected actions that would result in negative outcomes or risks for the firm.

Trust is central to all relational exchanges and is the cornerstone of the strategic partnership (Moorman and Deshpandé, and Zaltman, 1993; Morgan and Hunt, 1994). In the e-commerce environment, perceived risk is more pronounced than in traditional commerce. This is founded on three sources: 1) the electronic system - the Internet which is a relatively new and complex technology, whose security problems are frequently reported in the media; 2) the potential market partners - the online suppliers - who have the possibility to act opportunistically, and easily register and track customer data; 3) the customers themselves, who often have not yet gained much experience with this form of shopping, and therefore have not accumulated enough relevant knowledge about potential market partners as well as the process of how to shop online (Einwiller, Ingenhoff, and Schmid, 2003). Trust may take on a heightened importance in e-markets because of the spatial and temporal separation between buyers and sellers imposed by the medium. An Internet transaction does not typically involve the simultaneous exchange of money and goods, but instead they are typically transmitted from different locations and different times. When selecting a supplier, a customer must beware that the other party may be an expert in attracting traffic and in cashing credit cards, but not in actually delivering goods (Smith, Bailey, and Brynjolfsson, 1999). So, given the augmented perceived risks in the electronic environment, trust is even more important to long-term relationships between firms and their customers than in the traditional marketplace, and is a main determinant in the development of partners' cooperative efforts and actions. Considering these facts, we posit the following: 
Hypothesis 2: There is a positive relationship between trust and cooperation

\section{Antecedents of Relationship Commitment}

\section{The Effects of Trust on Relationship Commitment}

The relationship literature suggests that the future of buyer-seller relationships depends on the commitment made by the partners to the relationship, and that shortterm sacrifices are normally necessary to realize long-term benefits (Dwyer, Schurr, and Oh, 1987). Because relationships characterized by trust are so highly valued, partners will desire to commit themselves to such relationships (Morgan and Hunt, 1994).

In the e-market context, customers are considerably uncertain about matters of privacy, security for financial transactions, legal regulations, or proper delivery (Einwiller, Ingenhoff, and Schmid, 2003). Because commitment involves potential vulnerability and sacrifice, parties will seek only trustworthy partners, and firms are unlikely to be committed unless trust is already established (Garbarino and Johnson, 1999). In accordance with the theory of trust and commitment, we consider trust as a precursor of commitment (Morgan and Hunt, 1994), so we posit the following hypothesis:

\section{Hypothesis 3: There is a positive relationship between trust and relationship commitment}

\section{The Effect of Product Price and Acquisition Costs on Relationship Commitment}

Academic literature and business practice are directing increased attention to the importance of creating value in buyer-seller relationships. One way of creating value is to reduce costs in commercial exchanges. In fact, collaborative approaches seek to 
lower acquisition and operating costs through joint efforts of the buyer and supplier (Kalwani and Narayandas, 1995; Noordewier, John, and Nevin, 1990). The electronic market may provide significant cost savings, if compared with the traditional marketplace (Kalyanam and McIntyre, 2002; Sawhney and Zabin, 2002) - namely on customer's direct product costs and acquisition costs. Direct product cost is the actual price charged by the supplier for the main products sold to a customer. Because this cost is the most easily measured, it traditionally has received the most attention from buyers and sellers. Acquisition costs are defined as costs customers incur in acquiring and storing products from a particular supplier. They include expenses related to ordering, delivering, and storing products, as well as expenses of monitoring supplier performance and coordinating and communicating with the supplier. Lowering such costs has been the primary objective of the supply chain management movement in purchasing and logistics practice (Cannon and Homburg, 2001).

Supplier organizations may choose, or be asked, to make special accommodations for a customer. Accommodations may involve relaxing rules or policies in response to a customer's short-term needs, or establishing new policies and making major investments such as customizing products or routines, through flexibility or adaptation. A supplier may provide flexibility through modular product/ service offerings (Anderson and Narus, 1995)- e.g. a buying firm may order less frequently or carry less inventory if the supplier is flexible in responding to an occasional spike in demand from the buying firm, which lowers acquisition costs. Adaptation can be achieved through customizing products, services, systems and practices to the customer's needs, which also contributes to lower acquisition and other costs.

The e-marketing environment enables large-scale use of certain pricing mechanisms, such as forward auctions, reverse auctions, dynamic pricing, and "name your own 
price”, that are not widely feasible (Kalyanam and McIntyre, 2002). Furthermore, as Peppers and Rogers (1999) point out, relationship marketing has only recently become practical and cost-efficient on a large scale because of database technology and the internet, that allow the individual user to set their own preferences, and the firm to recognize a visitor in real time and configure its offerings digitally. In fact, in a B2B e-market context, key determinants in lowering customer costs, such as flexibility and adaptation potential, and the introduction of "time" into the exchange paradigm, namely in communication, searching supply, negotiating prices, and placing orders, enhance their value for both the supplier and the buyer (Narayandas, Caravella, and Deighton, 2002). As customer firms increasingly rely on tools such as value analysis in selecting and evaluating suppliers, suppliers that lower customer costs will be preferred. A supplier that enhances customer value by lowering customer costs will increase its "share of customer" at the expense of suppliers that do not provide such benefits (Cannon and Homburg, 2001), suggesting that when these benefits occur, the customer will enhance his commitment to the supplier. Therefore, we posit the following hypotheses:

\section{Hypothesis 4: There is a negative relationship between product prices and relationship commitment}

\section{Hypothesis 5: There is a negative relationship between acquisition costs and relationship commitment}

\section{The Effect of Termination Costs on Relationship Commitment}

Relationship literature assumes that a terminated party will seek an alternative relationship and have "switching” costs, which lead to dependence (Morgan and Hunt, 1994). Buyer switching costs may arise as a result of prior commitments to a 
technology and to a particular supplier, such as computers and communication systems requiring ongoing service or technical extension (Jackson, 1985), or through developing routines and procedures for dealing with a specific supplier that will need to be modified if a new relationship is established (Heide and John, 1990). In some situations, an entire set of working relationships will need to be established with different parts of the supplier's organization, such as technical support personnel and application specialists. All else being equal, buyers will be motivated to stay in existing relationships to economize on switching costs (Heide and Weiss, 1995).

These switching costs are enlarged by investments that make it difficult to switch to another relationship, such as lack of service and up-to-date information (Ganesan, 1994), to which we can add specific e-market's characteristics such as service convenience, difficult or impossible to re-deploy to another activity or channel. In fact, as mentioned by Ganesan (1994), the lack of alternatives is the primary cause of dependency, and dissolving the relationship is therefore not a viable solution in many situations.

When interdependence between supplier and buyer are balanced, partners exhibit a working consensus to collaborate (Spekman, Salmond, and Lambe, 1996). On the buyer side, dependency can be managed making investments in his relationship with the supplier, by engaging in bonding behaviors, enhancing the commitment to the vendor, and developing a stronger cooperative long-term relationship (Ganesan, 1994). In the e-market environment customers make significant investments in learning about technology, firm's products and business practices, in volume purchasing commitments, and in buying products and supporting infrastructure that is only available from specific firms (Sawhney and Zabin, 2002). Therefore, we posit the following hypothesis: 


\section{Hypothesis 6: There is a positive relationship between relationship termination costs and relationship commitment}

\section{The Effects of Relationship Benefits on Relationship Commitment}

Competition - particularly in the global marketplace - requires that firms continually seek out products, processes, and technologies that add value to their offerings. Relationship benefits may be represented by dimensions such as product profitability, customer satisfaction, product performance (Morgan and Hunt, 1994), or service convenience orientation, that researchers agree has a major impact on customers buying decisions, namely in the e-market context.

Service convenience is defined as customer's time and effort perceptions related to buying or using a service, for example operating hours, credit availability, service delivery (Berry, Seiders, and Grewal, 2002). In their research work aimed at presenting a more comprehensive and multidimensional conceptualization of service convenience, these authors suggest that the concept should be divided into different types, namely access convenience - perceived time and effort to initiate service delivery; transaction convenience - perceived expenditures of time and effort to effect a transaction; and post-benefit convenience - perceived time and effort expenditures when reinitiating contact with a firm after the benefit stage of the service. The authors also provide a conceptual framework and identify some items to guide further research in the domain of service convenience, which we followed in our study.

Uncertainty is mostly caused by the increasing variety and great variability of technological options, and these impact on the value propositions offered to the market, influencing at the same time the stability of demand preferences and the competitive positioning of the firm (Raimondo, 2000). Technology specifically 
designed to improve consumer convenience can affect each type of the service conveniences previously mentioned, e.g. intelligence embedded in an organization's information systems and available to service providers can improve not only information content but also speed of delivery. Technology can streamline service performance by automating manual processes that are slower and more error prone. Well-designed technologies can give consumers more control and more options, including the option to their own service provider. Sources of convenience may include better search tools, general suggestion tools, extensive product reviews, product samples (e.g., book chapters and CD audio clips), and faster checkout services (Smith, Bailey, and Brynjolfsson, 1999).

Database technology and the Internet allow an enterprise to track its customers individually across all touch points. Digital interaction on Web sites, at call centers, and through sales force automation tools now provides an automated connection to the firm. Mass customization technology permits a firm to configure its offerings digitally. This interaction is then likely to become part of an ongoing series of linked interactions, building a rich and individualized context for the relationship over time (Kalyanam and McIntyre, 2002). With each interaction, the offering can more closely meet the customer's needs. The relationship tends to get smarter and smarter, in what Peppers and Rogers (1999), called a “learning relationship”. In such an environment, the marketing functions defined from a relational exchange perspective are personalization (a form of customization), security, privacy, anytime-anywhere access, and customer service, which may be regarded as pre-acquisition and postacquisition relationship benefits. We suggest that suppliers that deliver superior benefits will be highly valued by their partners; in turn, these partners will commit 
themselves in their relationship with the supplier, which leads us to the following hypotheses:

Hypothesis 7: There is a positive relationship between pre-acquisition benefits and relationship commitment

Hypothesis 8: There is a positive relationship between post-acquisition benefits and relationship commitment

\section{Antecedent of both Relationship Commitment and Trust}

\section{The Effect of Policies and Practices}

Despite the well-recognized significance of trust building in customer-firm relationships, few studies have examined company behaviors and practices that build or deplete customer trust or the mechanisms by which these behaviors/practices contribute to trust enhancement and/or depletion (Sirdeshmukh, Singh, and Sabol, 2002). Therefore, although sufficient evidence exists to suggest that trust matters for critical relational outcomes, this paper pinpoints behaviors and management practices that are likely to be key drivers of both customer relationship commitment and trust. An important aspect of the definition of trust is the notion of a belief, a sentiment, or an expectation about an exchange partner that results from the partner's expertise, reliability, and intentionality, reflecting two distinct components 1) credibility, which is based on the extent to which the buyer believes that the supplier has the required expertise to perform the job effectively and reliably and 2) benevolence, which is based on the extent to which the customer believes that the supplier has intentions and motives beneficial to the customer (Ganesan, 1994). Moreover, regarding the component of credibility, Smith and Barclay (1997) find that perceptions of role competence have a significant effect on the partners to invest in the relationship, 
suggesting that the buyer perception of the supplier role competence has an impact on the customer relationship commitment.

Strategic considerations motivate organizations to build capabilities and preempt competition, and thereby to serve customers better. Considering the prominent role of technology in modern society, it comes as no surprise that organizations view technology as a means of building sustainable competitive advantage (Day and Glazer, 1994). Regarding the organizational decision to participate in electronic markets, strategic considerations such as providing better customer service (e.g. problem solving) gain particular significance (Grewal,, Comer, and Mehta, 2001).

Dwyer, Schurr, and Oh (1987) theorize that shared values contribute to the development of both commitment and trust. Similarly, Morgan and Hunt (1994) suggest that shared values, defined as the extent to which partners have beliefs in common about what behaviors, goals, and policies are important or unimportant, appropriate or inappropriate, and right or wrong, are direct precursors of both relationship commitment and trust. Nevertheless, these authors also suggest that the shared ethical values construct included in their research should be extended to other types, for example, relating to product quality, promotion tactics, or customer service, "as this could further the development of commitment and trust in relational exchange” (Morgan and Hunt, 1994, p. 32). Following this recommendation and the results of both the literature review and the qualitative exploratory stage, we decided to add to ethical values another component - problem solving orientation - defined as the customer's perception of the supplier's motivations to anticipate and satisfactorily resolve problems that may arise during and after a service exchange (Sirdeshmukh, Singh, and Sabol, 2002). In an electronic market environment, where problem-solving 
orientation has an important significance, we suggest that supplier policies and practices may impact on both relationship commitment and trust, as follows:

\section{Hypothesis 9: There is a positive relationship of policies and practices and relationship commitment}

\section{Hypothesis 10: There is a positive relationship of policies and practices and trust}

\section{Antecedents of Trust}

\section{The Effects of Opportunistic Behavior on Trust}

The issue of transaction costs is central to the study of organizations, and includes the costs of reaching an agreement that is satisfactory to both sides, adapting the agreement to unanticipated contingencies, and enforcing its terms (Ganesan, 1994). Because of bounded rationality and the costs of writing, negotiating, and implementing a contract, a comprehensive contract involving a long-term relationship is not possible. At best, only incomplete contracting can be achieved, increasing the possibility of one of the partners taking advantage of the other through opportunistic behavior, defined in the transaction cost analysis (TCA) literature as "self-interest seeking with guile” (Williamson, 1975, p.6). Incomplete contracting in a trusting relationship means that the two parties agree to adapt to unanticipated contingencies in a mutually profitable manner, responding to inequities through solutions over the long run instead of short-term opportunistic behavior, the hazards of which can be mitigated or removed if there is trust between the two parties in long-term relationships (Ganesan, 1994).

Although the concept of trust is now used in many disciplines, its study originated in the fields of psychology and sociology. Within these disciplines, trust appears to be defined by two constituent constructs: the first one is predictability of the behavior of 
the subject - or organization - in whom trust is placed, which comes from the learning process based on experience; the second one is the certainty that the person (or firm) concerned could not behave opportunistically and that his actions would be aimed to achieve joint benefits (Raimondo, 2000). In the virtual marketplace, where business is conducted at a distance and the actual delivering of goods represents a higher risk for the buyer, supplier opportunistic behavior becomes more obvious and easy to follow than in the traditional marketplace.

Incorporating trust in models of firm's relationships provides a unique vantage point of treating opportunistic behavior as an explanatory variable. In fact, for trust developing purposes, partners in a relationship must surpass this natural opportunistic behavior, resist the desire for an advantage, and instead work toward a mutually beneficial situation (Morgan and Hunt, 1994), which suggests the following hypothesis:

Hypothesis 11: There is a negative relationship between opportunistic behavior and trust.

\section{The Effects of Communication and Information Exchange on Trust}

Communication can be broadly defined as the formal as well as informal sharing of meaningful and timely information between firms (Anderson and Narus, 1990). This definition has as its focus the efficacy of information exchange rather than the quantity or amount, and the construct inherently taps past communications.

Communication and trust are two of the facets that compose cooperative competency, related to the ability of firms to assimilate and make use of new information or technologies, as well as to forge, develop, and govern partnerships (Sivadas and Dwyer, 2000). Cooperative competency manifests itself through the effective 
exchange of information a source of a firm's market orientation and sustainable competitive advantage (Day, 1991; Glazer, 1991; Porter and Millar, 1985), and successful partnerships are characterized by greater levels of trust, exhibiting better communication quality and information sharing (Mohr and Spekman, 1994).

The World Wide Web is a new medium characterized by ease of entry, globality, time independence and interactivity. As such, it represents a remarkable new opportunity for marketers to communicate with new and existing markets in a very integrated way (Berthon, Lane, Pitt, and Watson, 1998). Internet-based business-to-business emarkets represent an inter-organizational information system that facilitates electronic interactions among multiple buyers and sellers (Grewal, Comer, Mehta, 2001). In fact, in an electronic market environment, buyers and sellers come together in a marketspace and exchange information related to price, product specifications, and terms of trade, and a dynamic price-making mechanism facilitates transactions between the firms (Kaplan and Sawhney, 2000).

The inter-firm acquisition of information leads to richer and proprietary knowledge bases, and its distribution, interpretation, and utilization result in sustainable competitive advantages, by enhancing the value of firm's resources and organizational capabilities and by reducing uncertainty. The availability and depth of information are frequently mentioned as an important reason for shopping online, and in terms of information content, the ability to search price and quality information increases satisfaction with both the experience and product purchased and improves intentions to revisit and repurchase from a Web site (Zeithaml, Parasuraman, and Malhotra, 2002).

One factor that distinguishes firms that merely possess information from those that use information is the level of trust users have in producers of information (Moorman, 
Deshpandé and Zaltman, 1993). Because we test our model at a specific point in time, our definition of the construct corresponds to inherently past communication, as in previous studies (Anderson and Narus, 1990; Morgan and Hunt, 1994). Therefore, we posit that if a buyer's perception that past communications and information exchange from the supplier has been of high quality - that is, relevant, timely, and reliable - this will result in greater buyer trust, suggesting the following hypothesis:

\section{Hypothesis 12: There is a positive relationship between communication and information exchange and trust}

\section{Research Methodology}

\section{The Research Setting}

Usually an e-market is sponsored or maintained by a market maker, whose primary function is to gather buyers and sellers in a marketplace (Grewal et al., 2001; Klein and Quelch, 1997). Taking into account the objectives of this project, we selected PMElink.pt and its small and medium enterprise (SMEs) customers to test the proposed hypotheses. PMElink.pt is an online business centre that sells goods and services to SMEs in areas that support their core businesses. PMElink.pt was formed when three major Portuguese groups recognized an opportunity to market a variety of goods and services to their joint client base. Portugal Telecom is by far the leader in its sector, and two banks, Banco Espírito Santo and Caixa Geral de Depositos, are both leaders in the area of SMEs. Portugal Telecom's penetration is almost 100 percent and the two banks between them count as clients around 65 per cent of all SMEs operating within Portugal.

In the banks' day-to-day relationships with their clients, it was realized that they were often strong in their core businesses but very poor in support areas - clerical, office 
supplies and purchasing, IT, marketing, logistics and so on. An opportunity existed to take advantage of technology to give them the supporting tools they needed in these areas. PMElink.pt not only promises fast and efficient delivery of goods but also leverages cost reductions to its clients through bulk ordering and strategic sourcing of materials from key suppliers. In addition to products, PMElink.pt offers a range of business services, business expertise, advice and information through the same online connection. Essentially, PMElink.pt operates between diverse businesses and suppliers: a customer places an order with PMElink.pt, which is forwarded to one of their 30 suppliers; an express cargo carrier takes care of delivery logistics, and PMElink.pt bills the customer. Despite the apparent complexity of operations, PMElink.pt promises a 99 percent success rate for goods being delivered within a 24hour timeframe.

PMElink.pt selected an Internet and a CRM electronic platforms, to formulate an integrated e-business infrastructure and guarantee a reliable, scaleable and futureproof e-commerce solution. The integration between applications is also apparent in the provision of information and services and in personalization. For example, PMElink.pt recognized that SMEs often had difficulty dealing with various legal requirements; in response, it developed a package of core services that includes a search engine for all types of legal documents, a simulator for various fees and taxes, a fiscal calendar with reminders of major dates, and a library of printable official forms. Monitoring user activities on the site allows individual visitors to be segmented, so that campaigns can be targeted more effectively. Based on its unique relationship with its investors and customers, PMElink.pt aims to contact and start business with around 10 percent of the 200,000 SMEs operating in Portugal by the end of its third year of existence (May 2004). Using a reliable sample of their 
customers, our aim was to understand their perception of PMElink's economic, resources, and social relationship contents, and its impact on the creation and development of a marketing relationship process.

\section{Survey Instrument Development}

A questionnaire was developed that incorporates a variety of multi-item measures and indicators of the conceptual framework. Also included were additional indicators derived from exploratory interviews in the research context. The buyer-seller cooperation construct was adapted from Hewett and Bearden (2001). With regard to the mediating variables, relationship commitment was adapted from Anderson and Weitz (1992) and Kumar, Scheer e Steenkamp (1995), and trust was adapted from Morgan and Hunt (1994) and Anderson and Narus (1990). Both product prices and acquisition costs were adapted from Cannon and Homburg (2001), and termination costs and opportunistic behavior were adapted from Morgan and Hunt (1994). With regard to pre-acquisition benefits and post-acquisition benefits, we followed Berry, Seiders, and Grewal, (2002) convenience theory research suggestions. Regarding policies and practices, we adapted from Sirdeshmukh, Singh and Sabol, (2002). And finally, communication and information exchange were adapted from Sivadas and Dwyer (2000).

The content and face validity of the items was assessed by seven judges (two marketing professors and the five PMElink.pt managers). The survey was revised according to their comments and then given to a pretest sample of ten SME customer's purchasing managers. The pretest results were used to refine the questionnaire further. A full list of the final 36 items and their scale reliabilities can be found in Appendix 1. The average internal reliability (Cronbach alpha) was .83. 


\section{Data Collection}

In order to understand the buyer-seller cooperative relationship process, primary data were collected following a three stage methodology: 1) a qualitative exploratory stage, including in-depth interviews with a sample of managers of PMElink.pt, to identify the main ICT relationship benefits searched and perceived by SME customers, and meetings with selected SME customers, to understand their perceptions of ICT relationship benefits; 2) a survey stage, based on an online questionnaire, aimed at a sample of the SME customers, and directed to individuals responsible for products or services purchasing operations - ranging from general manager to purchasing or financial managers; and finally, 3) follow-up interviews, to discuss final results. The online survey, included in the firm periodic online newsletter, provided 395 valid questionnaires, above the minimum number (378) required for a $95 \%$ confidence level ${ }^{1}$.

\section{Sample Profile and Non Response Bias}

Respondents covered the main industry and economic activities, from the primary sector (5\%), to the industrial sector (21\%), and the services sector (74\%). They also selected and purchased from main product categories, as classified by the supplier: paper (74\%); consumable goods (73\%); other office products (57\%); systems equipment (29\%); office furniture (5\%); and services (6\%).

The survey was directed to individuals that are primarily responsible for purchasing activities, based on the supplier database. The job titles of the respondents ranged from general managers to financial managers, purchasing managers, and

\footnotetext{
${ }^{1}$ In line with previous studies conducted by PMElink.pt using the online periodic newsletter, stratified sampling, based on the customers' loyalty degree strata grouping, was established and achieved
} 
administrative managers (82\%); other job titles (18\%) correspond to staff that are normally responsible for contacting and dealing with the supplier, on a day-to-day basis. Collectively, this indicates that although the title of the respondents' positions may be wide-ranging, the individuals appear to have significant knowledge in the specific purchasing activities of the firm (Lages and Montgomery, 2004).

As previously discussed PMElink.pt completes in May 2004 its third year of existence. Naturally, the respondents firm's profile varied from less than 6 months (20\%) of business experience with the supplier, to more than 12 months (50\%), a high percentage of which above 2 years (70\%). Non-response bias was tested by assessing the differences between the early and late respondents with regard to the means of all the variables (Armstrong and Overton, 1977). No significant differences were found, suggesting that response bias was not a significant problem in the study. Data were analysed through exploratory factor analysis (EFA), followed by confirmatory factor analysis (CFA) and structural equation modelling (SEM).

\section{Data Analysis}

\section{Measurement Model Results}

In order to assess the validity of the measures, the items were subjected to a confirmatory factor analysis (CFA), using full-information maximum likelihood (FIML) estimation procedures in LISREL 8.3 (Jöreskog and Sörbom, 1993). In this model, each item was restricted to load on its pre-specified factor. The chi-square for this model is significant $\left(\chi^{2}=1088.45 ; 540 \mathrm{df}, \mathrm{p}=.000\right)$. However, since the chi-square statistic is sensitive to sample size, we also assessed additional fit indices. The Comparative Fit Index (CIF), the Incremental Fit Index (IFI), and the Non-Normative 
Fit Index (NNFI) of this model are .93, .94, and .94, respectively. We also accessed the Root Mean Square Error of Approximation (RMSEA), which accesses fit and incorporates a penalty for lack of parsimony. The RMSEA of this model is .051, indicating a good fit to the population.

Convergent validity is evidenced by the large and significant standardized loadings of each item on its intended construct (average loading size was .80). As shown in Appendix 1, all constructs present the desirable levels of composite reliability (Bagozzi, 1980). Discriminant validity among the constructs was also stringently assessed using the Fornell and Lacker (1981) test; all possible pairs of constructs passed this test. Discriminant validity was also evidenced by the correlation estimates between any two constructs (Jöreskog and Sörbom, 1993). No correlation includes the value of 1 (Anderson and Gerbing, 1988). Appendix 2 provides an overview of the construct means, standard deviations, and the correlation matrix among the constructs.

\section{Path Model Parameter Estimates}

The final structural model revealed a good fit $-\mathrm{CFI}=(.93), \mathrm{IFI}=(.94)$, and NNFI=(.94). All values observed reveal that the final model is good in reproducing the population covariance structure, and there is an acceptable discrepancy between the observed and predicted covariance matrices (Steiger, 1990). As observed in Table 1, all the predicted direct relationships are statistically significant. 
As can be seen, Table 1 shows that relationship commitment has a significant positive effect on their cooperation with the supplier $(.49, \mathrm{p}<.01)$, thus providing support to H1.

When testing H2, the results indicate that trust has a significant positive direct impact on buyer-supplier cooperation (.30, $\mathrm{p}<.01$ ), thus providing support for hypothesis H2. Moreover, as observed in Table 1 , the total positive effect $(.61, \mathrm{p}<.01)$ is strengthened by a significant indirect effect of trust on cooperation $(.32, \mathrm{p}<.01)$, through relationship commitment.

Regarding the impact of trust on relationship commitment, Table 1 shows a significant positive effect (.65, $\mathrm{p}<.01)$, thus providing support to $\mathrm{H} 3$.

There is a significant negative direct effect of product prices on relationship commitment $(-.10, \mathrm{p}<.05)$, thus providing support to hypothesis H4. Additionally, there is a negative indirect effect on cooperation $(-.05, \mathrm{p}<.05)$. There is no relationship between acquisition costs and relationship commitment (.00, ns), providing no support to H5.

The positive impact of termination costs on relationship commitment $(.26, \mathrm{p}<.01)$ is confirmed, thus providing support to hypothesis H6. Additionally there is a significant positive indirect impact on cooperation (.12, $\mathrm{p}<.01)$, through relationship commitment.

Surprisingly we did not find a relationship between both pre-acquisition and postacquisition benefits and relationship commitment hence we did not find support for either H7 or H8.

Regarding the impact of supplier policies and practices on relationship commitment, we did not find a significant positive direct effect. However it indirectly affects relationship commitment through trust $(.24, \mathrm{p}<.01)$, leading to a total significant 
positive effect $(.26, \mathrm{p}<.01)$. Hence, there is a partial support to hypothesis H9. Supplier policies and practices show a significant positive direct effect on trust (.36, $\mathrm{p}<.01$ ), thus supporting hypothesis H10. Additionally there is a significant positive indirect impact on cooperation $(.23, \mathrm{p}<.01)$.

There is a significant negative direct impact of opportunistic behavior on trust (-.19, $\mathrm{p}<.01$ ), thus providing support to H11. Additionally, there is a significant negative impact on relationship commitment $(-.13, \mathrm{p}<.01)$, through trust, and a significant negative indirect effect on cooperation $(-.12, \mathrm{p}<.01)$ through trust.

And finally, there is a significant direct effect of communication and information exchange on trust $(.11, \mathrm{p}<.05)$, thus providing support to H12. Additionally, there is a significant positive impact on relationship commitment $(.07, \mathrm{p}<.05)$ through trust, and a significant positive indirect effect on cooperation $(.07, \mathrm{p}<.05)$ through trust.

\section{Relative Importance of Predictor Variables}

The above discussion has focused upon the rows of Table 1. The following discussion will now consider the relative explanatory power of the predictor variables with respect to each of the three endogenous variables in the model, thus examining the columns of Table 1.

When analyzing the determinants of relationship commitment, Table 1 shows that the most powerful direct significant impact comes from trust $(.65, \mathrm{p}<.01)$, which is almost more than double the effect of termination costs $(.26, \mathrm{p}<.01)$, and more than six times the impact of product prices $(-.10, \mathrm{p}<.05)$. The strong direct impact of trust on relationship commitment also explains the significant indirect effect of three of the key determinants of cooperation on relationship commitment. Indeed, there is an impact of supplier policies and practices $(.24, \mathrm{p}<.01)$, followed by opportunistic 
behavior $(-.13, \mathrm{p}<.01)$, and communication and information exchange $(.07, \mathrm{p}<.05)$ on relationship commitment through trust.

Regarding the determinants of trust, we note that the main direct effect comes from the supplier policies and practices $(.36, \mathrm{p}<.01)$, which represents one and a half times opportunistic behavior $(.19, \mathrm{p}<.01)$, and more than three times the importance of communication and information exchange (.11, $\mathrm{p}<.05)$.

In terms of the determinants of cooperation, the most important direct effect is relationship commitment $(.49, \mathrm{p}<.01)$, followed by trust $(.30, \mathrm{p}<.01)$. However, when analyzing the total effects, trust comes in first place $(.61, \mathrm{p}<.01)$, followed by relationship commitment (.49, $\mathrm{p}<.01)$ supplier policies and practices $(.23, \mathrm{p}<.01)$, both termination costs $(-.12, \quad \mathrm{p}<.01)$ and opportunistic behavior $(.12, \mathrm{p}<.01)$, communication and information exchange $(.07, \mathrm{p}<.05)$, and finally product prices $(.05, \mathrm{p}<.05)$.

\section{Research Limitations}

There are some limitations to consider regarding the results. First, we offer the buyers' view as a starting point to understand the determinants of cooperation in this environment. In fact, the research relies on the responses of the buyers only providing an incomplete view of the relationship, one main reason being that the buyer-supplier relationship research, in an electronic market context, is still at an early stage (Morgan and Hunt, 2003). We offer the buyer view as a starting point to understand how they can foster trust and commitment from the suppliers (Jap and Ganesan, 2000). A second limitation is that our research instrument (i.e. the questionnaire) may have created common method variance. This could be particularly threatening if the respondents were aware of the conceptual framework of interest. However, they were 
not told the specific purpose of the study, and all of the construct items were separated and mixed (Jap 2001; Lages and Jap, 2003). Furthermore, we guaranteed confidentiality to all survey participants, which also helps to reduce the possibility of bias in trust, commitment, and cooperation for self-presentation reasons (Singh 2000; Lages and Lages, 2004). Third, the data are not longitudinal. For future research purposes the model developed and tested could benefit from being tested in a longitudinal design, as these studies provide for stronger inferences (Anderson and Narus, 1990; Morgan and Hunt, 1994). Fourth, a limitation may rely on the specific target of this study - Portuguese SMEs serviced by PMElink.pt. While enhancing the focus of this research, it may also limit the generalization of the results to some degree, at the same time creating the need for further studies in this field. In fact, it is hoped that shedding light on the use of new information and communication technologies will foster further works in their potential for the improvement of relationship marketing theory and practices.

\section{Discussion}

We have attempted to contribute to the knowledge and development of relationship marketing and e-markets. In fact, we have empirically provided an expansion of the key mediating variables (KMV) theory presented by Morgan's theoretical work (2000), to better understand the strategic nature of relationship marketing. As suggested by Morgan (2000, p.484), we expect in this way to "shed light on the processes and motivations of relationship building”. Regarding the electronic environment, the key to success is in offering benefits of comparable relevance to both buyers and sellers that are superior to their traditional transaction methods (Klein and Quelch, 1997). The research approach allows a better understanding of the extent 
to which the information and communication technologies (ICT) may impact on, and contribute to, the development of the buyer-seller cooperative relationship.

By empirically expanding the KMV theory, in an e-market context, we achieved some interesting findings. In the next section, we first discuss the implications of our research findings for relationship marketing and e-markets research, then speculate on some implications for marketing practice, and finally draw the conclusions of our research.

\section{Implications for Research in Relationship Marketing and E-Markets}

As a first result of our research, we found that the adapted Morgan and Hunt (1994) framework confirmed its robustness in a quite different environment - the electronic market context. In fact, as observed in Table 1, both of the mediating variables, relationship commitment and trust, show a very significant positive direct effect on cooperation, reinforcing the theory that suggests that "if cooperative relationships are required for relationship marketing success, our results suggest that commitment and trust are, indeed, key” (Morgan and Hunt, 1994, p.23). The results also show that the direct impact of commitment on cooperation is greater than trust, which also strengthens the theory that "relationships are built on the foundation of mutual commitment” (Berry and Parasuraman, 1991, p.139). Additionally, there is a significant positive direct impact of trust on commitment, thus confirming the theory suggesting that "firms are unlikely to be committed unless trust is already established" (Garbarino and Johnson, 1999, p.73). This relationship explains why the total effects of trust on cooperation are greater than commitment on cooperation.

Second, by extending the economic content of the KMV model - that is, by adding both product prices and acquisition costs to relationship termination costs (the only 
economic construct included in the KMV model) - we found a direct negative impact of product prices on cooperation, through the mediating effect of relationship commitment. Despite the reality showing that the majority of online shoppers are not out to score the absolute lowest price in the market (Reichheld and Schefter, 2000), buyers are price rational. Surprisingly, acquisition costs do not show a significant impact on relationship commitment in our findings. As mentioned during our followup interviews with PMElink.pt managers, an explanation may rely on the fact that SMEs do not normally control these costs, and seldom are aware of these costs' weight and importance in their total operational costs. As Morgan and Hunt (1994) explain, this may be reinforced by the fact that we asked respondents to compare their costs with the main supplier and with alternative suppliers. Many respondents may have a tendency to focus on the absolute level of costs, not the relative costs. Hence, future studies should try to measure absolute instead of relative levels of costs. Regarding termination costs, results confirm the theory that buyers will be motivated and committed to stay in existing relationships to economize on those costs (Heide and Weiss, 1995).

Third, we extended the resources contents by adding key online benefits. As in the KMV model, the hypothesized effect of relationship benefits on relationship commitment was unsupported (Morgan and Hunt, 1994, pp 32). We found no significant impact of these benefits on cooperation (such as convenience in product search and order processing, and payment security), through the mediating effect of relationship commitment. One of the possible explanations for this surprising finding may be that these benefits were measured comparing with those of alternative suppliers, as previously mentioned in the case of acquisition costs. Hence, future studies should try to measure satisfaction with absolute levels of benefits. Another reason may result from the "halo effect" suggested by Morgan 
and Hunt (1994, p. 32), through which the apparent relationship between benefits and commitment disappear when all exogenous variables (e.g. communication and information exchange) are included in the analysis. Another possibility might be that, before engaging in the relationship, customers already had a good perception of the supplier's founders' credibility and reliability - two of the most important national banks and the national telecom company - and extended the "security" image to the supplier. Fourth, regarding the social content (cf. Morgan and Hunt, 1994, p.484), we extended the sharing values construct (the KMV model included only ethical values) by adding “problem solving” practices. The empirical testing revealed that, although we did not find a direct impact of supplier policies and practices on relationship commitment, we found a significant direct positive effect on trust. These findings may be explained on the basis that the buyer-supplier relationship process is still in an early stage of development, when the parts involved are discovering and testing the goal compatibility, integrity, and performance, as well as potential obligations, benefits, and burdens involved with working together on a long-term basis (Dwyer, Schurr and Oh, 1987). It might be possible that the relationship will become significantly positive in the medium-long term.

Additionally, as in the KMV model, both communication and information exchange, and opportunistic behavior, show a significant direct effect on trust, positive and negative respectively, as well as an indirect effect on relationship commitment, through trust. This confirms that meaningful communication between firms in a working partnership is a necessary antecedent of trust, at any one point in time (Anderson and Narus, 1990). Moreover, trust depends on the perception that there is not opportunism from the counter-party (Raimondo, 2000). 


\section{Implications for Marketing Practice}

First of all, our findings show that relationship and customer's cooperative actions are possible to develop in an electronic environment, where perceived risk and uncertainty are highlighted if compared with traditional commerce, and that technology plays an important role for relationship management purposes (Sawhney and Zabin, 2002). In a context where most firms (such as SMEs) do not reckon the potential of e-marketing on influencing customer attitudes and behavior and the use of customer retention strategies, our findings may contribute to clarify these important key relationship phenomena.

Second, the findings also suggest that when it comes to customer relationship development purposes, even in an electronic environment, the old rules maintain their vitality. In fact, despite the innovative and quite different characteristics of the “marketspace”, compared with the traditional marketplace, the extended KMV maintains its robustness. When it comes to develop customer cooperative behavior, customer cooperation requires the supplier to be previously trustworthy, which then leads to customer commitment, in that order (Dwyer, Schurr and Oh, 1987; Jap and Ganesan, 2000). Managers willing to implement retention strategies and develop customer relationship processes should be aware, from the start, of the negative impact of opportunistic behavior and positive effects of customer oriented policies and practices, as well as reliable and meaningful information contents on trust. Not only are these considerations vital in terms of the supplier value chain organization, they may also be regarded as an important contribution to the customer value chain (Porter, 2001; Weiber and Kollman, 1998). 
Third, despite the majority of online shoppers not using the Internet to search for the absolute lowest price in the market (Reichheld and Schefter, 2000), B2B buyers are market price-driven. For this reason suppliers must regard their pricing policy as an important determinant of cooperation, through the mediating effect of commitment.

Fourth, as previously mentioned, customer acquisition costs do not show a significant impact on relationship commitment. One possible reason that SMEs do not realize the importance of these costs in their operational budget, as previously mentioned. Hence, we suggest that managers should develop with their customers a learning process, through which customers may become aware of the added value that might be achieved in their operational costs, by using the electronic channel. By doing so, it is possible to achieve a higher commitment and increased customer collaboration. In fact, the Technology Acceptance Model (TAM), which attempts to explain and predict why users sometimes accept or reject information systems (Davis, Bagozzi and Warshaw, 1989) confirms the importance and key role of the learning process in an e-market context. This is also confirmed by our follow-up interviews. During the first stage of the relationship process, around half of the human resources of PMElink.pt are dedicated to contact and teach customers how to work online with the technological system, namely by explaining its "usefulness" - the degree to which a person or firm believes that using a particular system would enhance his, her, or the firm's performance - and "ease of use" - the degree to which a person believes that using a particular system would be free of effort (Childers et al., 2001; Davis, 1989). Customers rely on their perceptions of usefulness and ease of use to form their intentions and technology acceptance behavior. However, after a period of actually using the system, the ease of use is depicted as having an indirect effect on intentions, meaning that subsequent intentions to use and usage behavior is formed from the 
customers’ perceptions of the system’s usefulness (Szajna, 1996). This fact may help to explain the low impact of "convenience" benefits on cooperation, as it may be partly perceived and included in the "ease of use” belief.

\section{Conclusions}

The technology impact on relationship marketing represents one of the most serious challenges to firms. Our research allows us to reinforce the idea that the customer relationship process needs to be regarded by academics and practitioners as a longterm rewarding process, even in an electronic and real time environment. The main determinants of customer cooperation rely mainly on trust and commitment. Commitment development requires the previous achievement of trust. As a starting point, this fact enhances the importance of establishing the adequate chain value activities that lead to customer trust, such as relationship policies and practices, communication and meaningful information exchange facilities, and the fulfillment of all forwarded promises, not forgetting that suppliers need to pay special attention to their pricing policy. In the electronic market context, marketing is required to perform new roles, such as customer support service (Kalyanam and McIntyre, 2002) that is associated with trust, commitment, and cooperation. To conclude, suppliers should also be aware that as the relationship process develops, customers make significant investments in learning about a firm's products and business practices and supporting infrastructure that are only available from specific firms (Sawhney and Zabin, 2002). These investments represent very good reasons for buyers' commitment development (resulting in higher product purchases and meaningful information exchange) and a stronger cooperative long-term relationship with the supplier. 
Figure 1: Conceptual Model of the Determinants of Cooperation in an Electronic Market Context

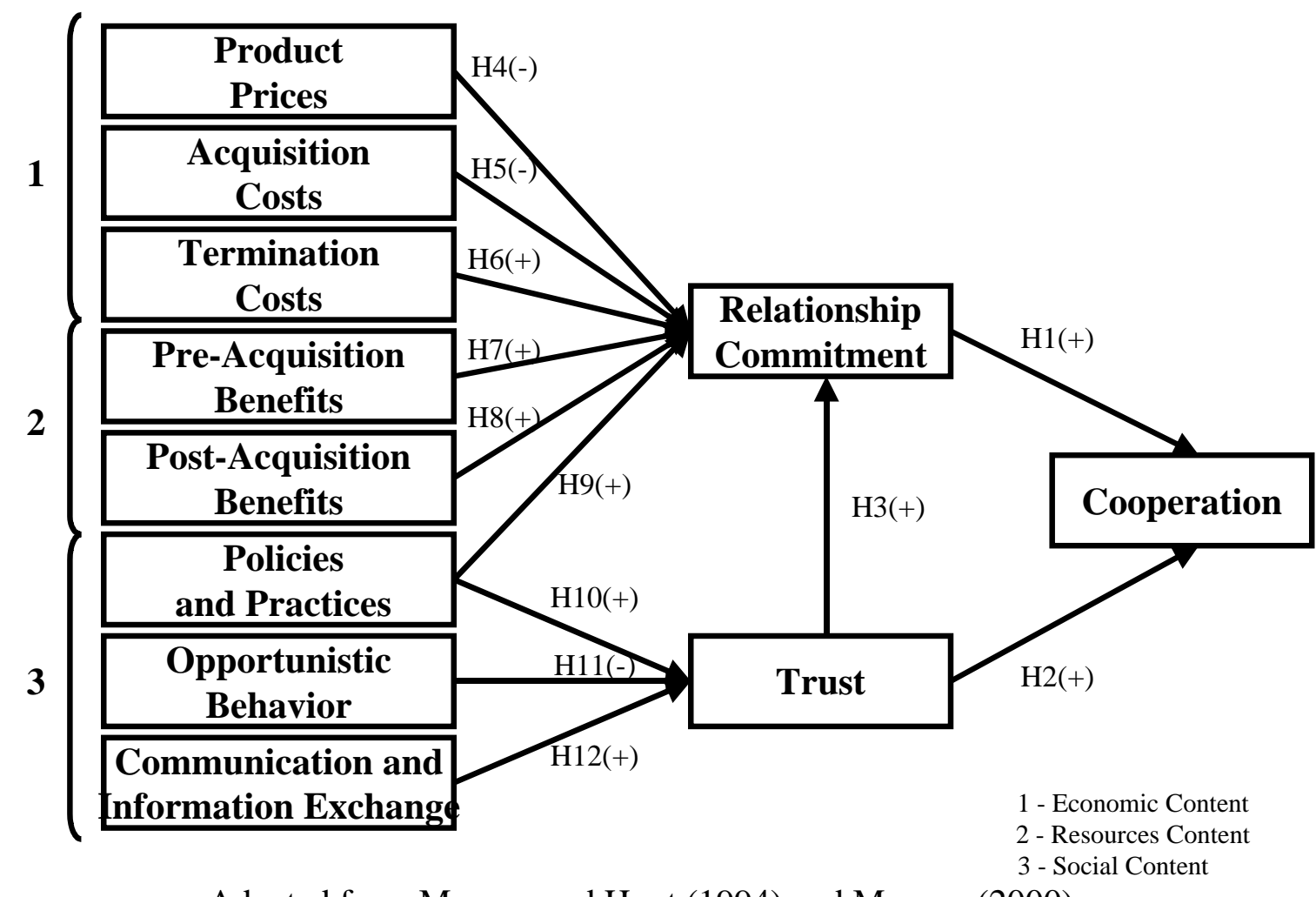

Adapted from Morgan and Hunt (1994) and Morgan (2000) 
Table 1: Effects of exogenous and prior endogenous constructs

(Maximum likelihood estimation, $\mathrm{N}=395$ )

\begin{tabular}{|c|c|c|c|c|c|c|c|c|c|}
\hline \multirow[t]{2}{*}{ EFFECT OF/ ON } & \multicolumn{3}{|c|}{$\begin{array}{c}\eta 1 \\
\text { Relationship } \\
\text { Commitment }\end{array}$} & \multicolumn{3}{|c|}{$\begin{array}{c}\eta^{2} \\
\text { Trust }\end{array}$} & \multicolumn{3}{|c|}{$\begin{array}{c}\eta 3 \\
\text { Cooperation }\end{array}$} \\
\hline & Direct & Indirect & Total & Direct & Indirect & Total & Direct & Indirect & Total \\
\hline $\begin{array}{c}\eta 1 \\
\text { Relationship } \\
\text { Commitment }\end{array}$ & & & & & & & $\begin{array}{c}0.49 \\
6.40 \\
\text { H1 } \\
\end{array}$ & & $\begin{array}{l}0.49 \\
6.40\end{array}$ \\
\hline $\begin{array}{c}\eta 2 \\
\text { Trust }\end{array}$ & $\begin{array}{c}0.65 \\
9.72 \\
\mathrm{H3} \\
\end{array}$ & & $\begin{array}{l}0.65 \\
9.72\end{array}$ & & & & $\begin{array}{l}0.30 \\
4.41 \\
\mathrm{H} 2 \\
\end{array}$ & $\begin{array}{l}0.32 \\
6.05\end{array}$ & $\begin{array}{c}0.61 \\
10.30\end{array}$ \\
\hline $\begin{array}{c}\xi 1 \\
\text { Product Prices }\end{array}$ & $\begin{array}{c}-0.10 \\
-2.45 \\
\mathrm{H} 4 \\
\end{array}$ & & $\begin{array}{r}-0.10 \\
-2.45\end{array}$ & & & & & $\begin{array}{r}-0.05 \\
-2.34\end{array}$ & $\begin{array}{l}-0.05 \\
-2.31\end{array}$ \\
\hline $\begin{array}{c}\xi 2 \\
\text { Acquisition } \\
\text { Costs }\end{array}$ & $\begin{array}{c}0.00 \\
-0.05 \\
\mathbf{H 5}\end{array}$ & & $\begin{array}{r}0.00 \\
-0.05\end{array}$ & & & & & $\begin{array}{r}0.00 \\
-0.05\end{array}$ & $\begin{array}{r}0.00 \\
-0.05\end{array}$ \\
\hline $\begin{array}{c}\xi 3 \\
\text { Termination Costs }\end{array}$ & $\begin{array}{c}0.26 \\
4.91 \\
\text { H6 } \\
\end{array}$ & & $\begin{array}{l}0.26 \\
4.91\end{array}$ & & & & & $\begin{array}{l}0.12 \\
4.19\end{array}$ & $\begin{array}{l}0.12 \\
4.19\end{array}$ \\
\hline $\begin{array}{c}\xi 4 \\
\begin{array}{c}\xi r e-A c q u i s i t i o n \\
\text { Benefits }\end{array} \\
\end{array}$ & $\begin{array}{c}0.07 \\
0.87 \\
\mathbf{H 7} \\
\end{array}$ & & $\begin{array}{l}0.07 \\
0.87\end{array}$ & & & & & $\begin{array}{l}0.03 \\
0.87\end{array}$ & $\begin{array}{l}0.03 \\
0.87\end{array}$ \\
\hline $\begin{array}{c}\xi 5 \\
\text { Post- Acquisition } \\
\text { Benefits }\end{array}$ & $\begin{array}{c}-0.14 \\
-1.40 \\
\text { H8 }\end{array}$ & & $\begin{array}{l}-0.14 \\
-1.40\end{array}$ & & & & & $\begin{array}{l}-0.07 \\
-1.38\end{array}$ & $\begin{array}{l}-0.07 \\
-1.38\end{array}$ \\
\hline $\begin{array}{c}\xi 6 \\
\text { Policies and Practices }\end{array}$ & $\begin{array}{c}0.03 \\
0.44 \\
\mathbf{H 9}\end{array}$ & $\begin{array}{l}0.24 \\
5.15\end{array}$ & $\begin{array}{l}0.26 \\
3.82\end{array}$ & $\begin{array}{l}0.36 \\
5.75 \\
\text { H10 }\end{array}$ & & $\begin{array}{l}\mathbf{0 . 3 6} \\
\mathbf{5 . 7 5}\end{array}$ & & $\begin{array}{l}0.23 \\
4.83\end{array}$ & $\begin{array}{l}0.23 \\
4.83\end{array}$ \\
\hline $\begin{array}{c}\xi 7 \\
\text { Opportunistic Behavior }\end{array}$ & & $\begin{array}{r}-0.13 \\
-3.48\end{array}$ & $\begin{array}{r}-0.13 \\
-3.48\end{array}$ & $\begin{array}{r}-0.19 \\
-3.64 \\
\text { H11 } \\
\end{array}$ & & $\begin{array}{l}-0.19 \\
-3.64\end{array}$ & & $\begin{array}{l}-0.12 \\
-3.51\end{array}$ & $\begin{array}{l}-0.12 \\
-3.51\end{array}$ \\
\hline $\begin{array}{c}\xi 8 \\
\text { Communication and } \\
\text { Information Exchange }\end{array}$ & & $\begin{array}{l}0.07 \\
1.97\end{array}$ & $\begin{array}{l}0.07 \\
1.97\end{array}$ & $\begin{array}{l}0.11 \\
2.00 \\
\text { H12 }\end{array}$ & & $\begin{array}{l}0.11 \\
2.00\end{array}$ & & $\begin{array}{l}\mathbf{0 . 0 7} \\
1.97\end{array}$ & $\begin{array}{l}0.07 \\
1.97\end{array}$ \\
\hline
\end{tabular}

Notations: Values above are completely standardized estimates; values below are t-values; values in bold are significant effects. Because of rounding, sometimes the "total effect" is not the same as "the direct effect plus the indirect effect”. 


\section{Appendix 1: Final scale items and reliabilities}

Cooperation $\left(\alpha=.86 ; \rho=.86 ; \rho_{v c(n)}=.68\right)$

Please rate your agreement with each of the following statements, regarding your relationship activities with PMElink.pt (the supplier)

Scale: $1=$ Strongly Disagree; $7=$ =Strongly Agree

a) My firm and the supplier regularly interact

b) There is an open communication between our firms

c) Overall, we are satisfied with the interaction with the supplier

Relationship Commitment $\left(\alpha=.86 ; \rho=.87 ; \rho_{v c(n)}=.57\right)$

Please rate your agreement with each of the following statements, regarding your relationship with PMElink.pt (the supplier)

Scale: 1=Strongly Disagree; 7=Strongly Agree

a) We have a strong sense of loyalty to the supplier

b) We expect to be using the supplier for some time

c) Our relationship with the supplier is a long-term partnership

d) We would not drop the supplier because we like being associated with it

e) We want to remain as a customer of the supplier because we have pride in being associated with a firm that carries a technological image

Trust $\left(\alpha=.92 ; \rho=.93 ; \rho_{v c(n)}=.72\right)$

Please rate each of the following statements:

1) In our relationship, PMElink.pt (the supplier)

Scale: $1=$ Strongly Disagree; $7=$ Strongly Agree
a) Is perfectly truthful
b) Is someone to whom I give my confidence
c) Has high integrity
d) Gives us reliable information and advice

2) Overall, how would you characterize the level of trust your company has in its working relationship with PMElink.pt (the supplier)?

Scale: 1) Do Not Trust At All; 7) Totally Trust 


\section{Economic Content}

\section{Product Prices}

How do you compare the (catalog) prices of PMElink.pt (the supplier) with the prices of alternative suppliers?

Scale: 1) Prices are much lower; 7) Prices are much higher)

a) Product prices

Acquisition Costs $\left(\alpha=.91 ; \rho=.91 ; \rho_{v c(n)}=.66\right)$

How do you each of the following costs incurred with PMElink.pt (the supplier) compare with costs incurred with alternative suppliers?

Scale: 1) Costs are much lower; 4) Costs are the same; 7) Costs are much higher)

a) Product searching and selecting costs

b) Product and services ordering costs

c) Stocks and inventory carrying costs

d) Costs of communication between your firm and this supplier

e) Administrative costs

Termination Costs $\left(\alpha=.80 ; \rho=.81 ; \rho_{v c(n)}=.59\right)$

Please rate your agreement with each of the following statements:

If we decided to leave PMElink.pt (the supplier)...

Scale: $1=$ Strongly Disagree; $7=$ Strongly Agree

a) We are afraid of what might happen without having another supplier lined up

b) Our business would be greatly disturbed

c) It would represent an important loss to us

\section{Resources Content}

Pre-Acquisition Benefits $\left(\alpha=.80 ; \rho=.81 ; \rho_{v c(n)}=.60\right)$

How do you compare PMElink.pt (the supplier) with an alternative supplier, with whom you work with, or have worked before, in terms of...

Scale: 1) Much Worse; 4) The Same; 7) Much Better

a) Product assortment and variety

b) Ease of product search and selection

c) Ease of order processing

Post-Acquisition Benefits $\left(\alpha=.71 ; \rho=.72 ; \rho_{v c(n)}=.57\right)$

How do you compare PMElink.pt (the supplier) with an alternative supplier, with whom you work with, or have worked before, in terms of...

Scale: 1) Much Worse; 4) The Same; 7) Much Better

a) Payment security

b) Service delivery quality consistency 


\section{Social Content}

Policies and Practices $\left(\alpha=.81 ; \rho=.82 ; \rho_{v c(n)}=.61\right)$

Please rate your agreement with each of the following statements, regarding PMElink.pt (the supplier)

Scale: $1=$ Strongly Disagree; $7=$ =Strongly Agree

a) The supplier has policies that show respect for the customer

b) The supplier has practices that make solving problems easy

c) The supplier solves my firm's problems quickly

Opportunistic Behavior $\left(\alpha=.89 ; \rho=.90 ; \rho_{v c(n)}=.74\right)$

To accomplish its own objectives, sometimes PMElink.pt (the supplier)....

Scale: $1=$ Strongly Disagree; $7=$ Strongly Agree
a) Alters the facts slightly
b) Promises to do things without doing them later
c) Fails to provide us with the support that they are obliged to

Communication and Information Exchange $\left(\alpha=.84 ; \rho=.84 ; \rho_{v c(n)}=.65\right)$

How do you compare PMElink.pt (the supplier) with an alternative supplier, with whom you work with, or have worked before, in terms of communication and information?

Scale: 1) Much Worse; 4) The Same; 7) Much Better

a) Provides relevant information to our firm

b) Provides on-time information

c) Guarantees privacy on the sharing of information 
Appendix 2: Means, standard deviations, and correlations among constructs

\begin{tabular}{|c|c|c|c|c|c|c|c|c|c|c|c|c|c|}
\hline Constructs & Means & S.D. & 1 & 2 & 3 & 4 & 5 & 6 & 7 & 8 & 9 & 10 & 11 \\
\hline 1. Cooperation & 4.5 & 1.20 & 1 & & & & & & & & & & \\
\hline 2. Commitment & 4.3 & 1.21 & $.619 * *$ & 1 & & & & & & & & & \\
\hline 3. Trust & 5.2 & 1.09 & $.574 * *$ & $.659 * *$ & 1 & & & & & & & & \\
\hline $\begin{array}{l}\text { 4. Product } \\
\text { Prices }\end{array}$ & 3.6 & 1.16 & $-.220 * *$ & $-.267 * *$ & $-.180 * *$ & 1 & & & & & & & \\
\hline $\begin{array}{l}\text { 5. Acquisition } \\
\text { Costs }\end{array}$ & 3.4 & 1.16 & $-.129 *$ & $-.186 * *$ & $-.208 * *$ & $.404 * *$ & 1 & & & & & & \\
\hline $\begin{array}{l}\text { 6. Termination } \\
\text { Costs }\end{array}$ & 3.0 & 1.42 & $.315^{* *}$ & $.372 * *$ & $.232 * *$ & $-.283^{* *}$ & $-.143 * *$ & 1 & & & & & \\
\hline $\begin{array}{l}\text { 7. Pre-Acquisition } \\
\text { Benefits }\end{array}$ & 4.8 & 1.14 & $.233^{* *}$ & $.222 * *$ & $.256 * *$ & $-.303^{* *}$ & $-.244^{* *}$ & $.273^{* *}$ & 1 & & & & \\
\hline $\begin{array}{l}\text { 8. Post-Acquisition } \\
\text { Benefits }\end{array}$ & 4.9 & 1.08 & $.225 * *$ & $.265^{* *}$ & $.325^{* *}$ & $-.339 * *$ & $-.264^{* *}$ & $.342 * *$ & $.606^{* *}$ & 1 & & & \\
\hline $\begin{array}{l}\text { 9. Policies } \\
\text { and Practices }\end{array}$ & 5.1 & 1.06 & $.335 * *$ & $.385 * *$ & $.467 * *$ & $-.304^{* *}$ & $-.234^{* *}$ & $.315^{* *}$ & $.388 * *$ & $.424 * *$ & 1 & & \\
\hline $\begin{array}{l}\text { 10. Opportunistic } \\
\text { Behavior }\end{array}$ & 2.4 & 1.36 & $-.245^{* *}$ & $-.227 * *$ & $-.328 * *$ & $.205^{* *}$ & $.305^{* *}$ & -.097 & $-.162 * *$ & $-.157 * *$ & $-.351 * *$ & 1 & \\
\hline $\begin{array}{l}\text { 11. Communication } \\
\text { and Information } \\
\text { Exchange }\end{array}$ & 4.7 & 1.05 & $.239 * *$ & $.189 * *$ & $.290 * *$ & $-.269 * *$ & $-.248 * *$ & $.264 * *$ & $.465 * *$ & $.444 * *$ & $.430 * *$ & $-.167 * *$ & 1 \\
\hline
\end{tabular}




\section{References}

Anderson, E. and B. Weitz (1992), "The use of pledges to build and sustain commitment in distribution channels”, Journal of Marketing Research, 29, February, 18-34

Anderson, J., and D.Gerbing (1988), "Structural equation modeling in practice: a review and recommended two-step approach”, Psychological Bulletin, 103, No.3, May, 411-423

Anderson, J.and J. Narus (1990), “A model of distributor firm and manufacturer firm working partnerships”, Journal of Marketing, 54, January, 42-58

Armstrong, J. and T. Overton (1977), "Estimating non-response bias in mail surveys", Journal of Marketing Research, 16, August, 396-400

Bagozzi, R. (1980), Causal Models in Marketing. New York: John Wiley

Berry, L and A. Parasuraman (1991), "Marketing services: competing through quality”, New York, The Free Press

Berry, L., K. Seiders, and D.Grewal (2002), “Understanding service convenience”, Journal of Marketing, 66, July, 1-17

Berthon P., N. Lane, L. Pitt, and R.Watson (1998), "The world wide web as an industrial marketing communication tool: models for the identification and assessment of opportunities”, Journal of Marketing Management, 14, 691-704

Blois, K. (1996), “ Relationship marketing in organizational markets: when is it appropriate?”, Journal of Marketing Management, .12, 161-173

Cannon, J. and C. Homburg (2001) "Buyer-seller relationships and customer firm costs", Journal of Marketing, 65, January, 29-43

Childers, T., C. Carr, J. Peck, and S.Carson (2001) "Hedonic and utilitarian motivations for online retail shopping behaviour”, Journal of Retailing, 77, No.4, Winter, 511-535

Coviello, N., R. Milley and B. Marcolin (2001), "Understanding it-enabled interactivity in contemporary marketing”, Journal of Interactive Marketing, 15, No.4, October, 18-33

Davis, F. (1989) "Perceived usefulness, perceived ease of use, and user acceptance of information technology”, MIS Quartely, 13, No.3, 318-340

Davis, F., R. Bagozzi, and P.Warshaw (1989), "User acceptance of computer technology: a comparison of two theoretical models”, Management Science, 35, 982-1002

Day, G. (1991), "Learning about markets”, Marketing Science Institute Report, p. 91-117, Cambridge, MA: Marketing Science Institute

Day, G. and R. Glazer (1994), "Harnessing the marketing information revolution: towards the market-driven learning organization”, in The Marketing Information Revolution, R.C. Blattberg, R. Glazer, and J.D.C. Little, eds. Boston: Harvard Business School Press, 270-288

Dertouzos, M., R. Lester and R. Solow (1989), "Made in America: regaining the productive edge”, Cambridge, MA, The MIT Press

Doney, P. and J. Cannon (1997), “An examination of the nature of trust in buyer-seller relationships”, Journal of Marketing, 61, no2, April, 35-51

Dwyer, F.R., P.Schurr, and S. Oh (1987), “Developing buyer-seller relationships”, Journal of Marketing, 51, April, 11-27 
Einwiller, S., D. Ingenhoff, D, and B. Schmid (2003), “A model of trust and reputation in electronic commerce", in Proceedings from the EMAC $32^{\text {nd }}$ Conference, University of Strathclyde, Glasgow

Fornell, C. and D. Larcker (1891), "Evaluating structural equation models with unobservable variables and measurement error”, Journal of Marketing Research, 18, Feb, 39-50

Garbarino, E. and M. Johnson (1999), "The different roles of satisfaction, trust and commitment in customer relationships”, Journal of Marketing, 63, April, 70-89

Grewal, R., J. Comer and R. Mehta (2001), "An investigation into the antecedents of organizational participation in business-to-business electronic markets", Journal of Marketing, 65, July, 17-33

Gummesson, E. (1994), "Making relationship marketing operational”, The International Journal of Service Industry Management, 5, No..5, 5-20

Heide, J. and A. Weiss (1995), "Vendor consideration and switching behavior for buyers in high-technology markets”, Journal of Marketing, 59, July, 30-43

Heide, J. and G. John (1990), "Alliances in industrial purchasing: the determinants of joint action in buyer-seller relationships", Journal of Marketing Research, 27, February, 2436

Hewett, K. and W. Bearden (2001), "Dependence, trust, and relational behaviour on the part of foreign subsidiary marketing operations: implications for managing global marketing operations”, Journal of Marketing, 65, October, 51-66

Jap, S. D. (2001), "Pie-sharing in complex collaboration contexts", Journal of Marketing Research, 38, Feb, 86-99

Jap, S. D., and S. Ganesan (2000), "Control mechanisms and the relationship life cycle: implications for safeguarding specific investments and developing commitment", Journal of Marketing Research, 37, May, 227-245

John, G., A. Weiss, and D. Shantanu (1999), "Marketing in technology-intensive markets: toward a conceptual framework", Journal of Marketing, 63, Special Issue, 78-91

Jöreskog, K. and D. Sörbom (1993), LISREL 8: Structural Equation Modeling with the SIMPLIS Command Language, Hillsdale, NJ: Lawrence Erlbaum Associates

Kalyanam, K. and S. McIntyre (2002), "The e-marketing mix: a contribution of the e-tailing wars”, Journal of the Academy of Marketing Science, 30, no.4, Fall, 487-499

Kalwani, M., and N. Narayandas (1995), "Long-term manufacturer-supplier relationships: do they pay off for supplier firms?, Journal of Marketing, 59, January, 1-16

Klein, L. and J. Quelch (1997), "Business-to-business market making on the internet”, International Marketing Review, 14, no.5, 345-361

Kumar, N., L. Scherr and J.B. Steenkamp (1995), "The effects of perceived interdependence on dealer attitudes”, Journal of Marketing Research, 32, 348-356

Lages, L. F. and S. D. Jap (2003), "The relationship among past performance, marketing mix adaptation, and current export performance improvement in global marketing relationships", Proceedings of the MSI/IJRM Competition, Conference on Global Marketing, Noordwijk, Netherlands: Marketing Science Institute.

Lages, L. F. and D. B. Montgomery (2004), "Export performance as an antecedent of export commitment and marketing strategy adaptation: evidence from small and medium sized exporters." European Journal of Marketing, in print. 
Lages, L. F. and C. R. Lages (2004), "The STEP scale: A measure of short-term export performance improvement”, Journal of International Marketing, 12(1), 36-56.

McKenna, R. (1997), Real Time - preparing for the age of the never satisfied customer, Harvard Business School Press, Boston, Massachusetts

Mohr, J. and R. Speckman (1994), "Characteristics of partnership success: Partnership attributes, communication behavior and conflict resolution techniques", Strategic Management Journal, 57, 135-149

Moorman C., G. Zaltman, and R. Deshpandé (1992), "Relationship between providers and users of market research: the dynamic of trust within and between organizations", Journal of Marketing Research, 29, No.3, 314-328

Moorman, C., R. Deshpandé, and G. Zaltman (1993), "Factors affecting trust in market research relationships”, Journal of Marketing, 57, January, 81-101

Morgan, R. (2000), in Sheth, J. and A. Parvatiyar (2000), Handbook of Relationship Marketing, Sage Publications

Morgan, R. and S. Hunt (1994), "The commitment-trust theory of relationship marketing”, Journal of Marketing, 58 July, 20-38

Morgan, R. and S. Hunt (2003) “An interview with Dr. Rob Morgan \& Dr. Shelby Hunt, in http://www.incites.com/papersMMorgan_n_Hunt.html (accessed 5- 01-2004)

Narayandas, D., M. Caravella, and J. Deighton (2002), "The impact of internet business-tobusiness distribution", Journal of the Academy of Marketing Science, 30, No.4, Fall, 500-505

Noordewier, T., G.John, and J.Nevin (1990), "Performance outcomes of purchasing arrangements in industrial buyer-vendor relationships”, Journal of Marketing, 54, October, 80-93

Peppers, D., and M. Rogers (1999),’Is your company ready for one-to-one marketing?”, Harvard Business Review, Jan-Feb, 151-160

Podsakoff, P., and Organ, D. (1986), "Self-reports in organizational research: problems and perspectives”, Journal of Management, 12, No.4, 531-544

Porter, Michael (2001), “Strategy and the internet”, Harvard Business Review, March, 63-78

Porter, M, and V. Millar (1985), "How information gives you competitive advantage”, Harvard Business Review, 85 (July-August), 149-60

Raimondo, M.A. (2000), "The measurement of trust in marketing strategies: a review of models and methodologies", in Proceedings of the IMP Conference 2000, http://www.bath.ac.uk/management/imp/pdf/14_raimondo.pdf (accessed 28-07-2003)

Rayport, J. and J. Sviokla (1995), “Exploiting the virtual value chain”, Harvard Business Review, Nov-Dec, 75-85

Reichheld, F., and P. Schefter (2000), "E-loyalty: your secret weapon on the web”, Harvard Business Review, July-August, 105-113

Reichheld, F. and W. Sasser (1990), "Zero defections: quality comes to services”, Harvard Business Review, 68, Sep-Oct, 105-111

Sawhney, M., and J. Zabin (2002) "Managing and measuring relational equity in the network economy”, Journal of the Academy of Marketing Science, 30, No.4, Fall, 313-332

Singh, J. (2000), "Performance productivity and quality of frontline employees in service organizations”, Journal of Marketing, 64, April, 15-34 
Sirdeshmukh., J. Singh, J and B. Sabol (2002), "Consumer trust, value, and loyalty in relational exchanges”, Journal of Marketing, 66, January, 15-37

Sivadas, E. and F.R. Dwyer (2000), "An examination of organizational factors influencing new product success in internal and alliance-based processes", Journal of Marketing, 64, January, 31-49

Smith, A. and Barclay, D. (1997) "The effects of organizational differences and trust on the effectiveness of selling partner relationships”, Journal of Marketing, 61, January, 3-21

Speckam, R., D. Salmond and C. Lambe (1996), "Consensus and collaboration: normregulated behavior in industrial marketing relationships", European Journal of Marketing, 31, No.11/12, 832-856

Steiger, J. (1990) "Structural model evaluation and modification: an interval estimation approach”, Multivariate Behavioral Research, 25, 173-180

Szajna, B. (1996), "Empirical evaluation of the revised technology acceptance model", Management Science, 42, No.1, January, 85-92

Too, A., A. Souchon and P. Thirkell (2001), "Relationship Marketing and customer loyalty in a retail setting: a dyadic exploration”, Journal of Marketing Management, 17, 287-319

Varadarajan, P.R., and M. Yadav(2002), "Marketing strategy and the internet: an organizing framework", Journal of the Academy of Marketing Science, 30, No.4, 296-312

Weiber, R. and T. Kollman (1998), "Competitive advantages in virtual markets perspectives of information-based marketing in cyberspace”, European Journal of Marketing, 32, No. 7/ 8, 603-615

Williamson, O. (1975), Markets and Hierarchies: Analysis and Antitrust Implications. New York: The Free Press

Williamson, O. (1985), The Economic Institutions of Capitalism: Firms, Markets, Relational Contracting. New York, The Free Press

Zeithaml, V., A. Parasuraman and A. Malhotra (2002), "Service quality delivery through web sites. a critical review of extant knowledge", Journal of the Academy of Marketing Science”, 30, No.4, 362-375 